\section{Rooting Cuttings in Cupric Hydroxide- treated Pots Affects Root Length and Number of Flowers after Transplanting}

\author{
Sven E. Svenson ${ }^{1}$ and Diane L. Johnston ${ }^{2}$ \\ Fort Lauderdale Research and Education Center, University of Florida, 3205 \\ College Avenue, Fort Lauderdale, FL 33314
}

Additional index words. Evolvulus glomeratus, Evolvulus tenuis, Lantana camara, Lantana montevidensis

\begin{abstract}
Stem tip cuttings of Evolvulus glomeratus Nees \& Mart., E. tenuis Nees \& Mart., Lantana camara L. 'Dallas Red,' and L. montevidensis Briq. 'Alba' were rooted for 6 weeks in 57-mm-diameter $(150 \mathrm{ml})$ square pots. Before rooting, interior surfaces of half of the pots were treated with $100 \mathrm{~g} \mathrm{Cu}(\mathrm{OH})_{2}$ /liter, while remaining pots were left untreated. Elongation of adventitious roots stopped when root tips came in contact with a $\mathrm{Cu}(\mathrm{OH})_{2}$ treated surface. Cupric hydroxide treatment reduced total root length and the length of the longest root for all four species, but did not influence root, shoot, or total plant weight. One month after transplanting to $150-\mathrm{mm}$-diameter (1.2 liter) hanging baskets, plants moved from $\mathrm{Cu}(\mathrm{OH})_{2}$-treated pots had more flowers than those transplanted from nontreated pots. Applying $\mathrm{Cu}(\mathrm{OH})_{2}$ to interior surfaces of pots used for propagation prevented root deformation, reduced root length, and increased flowering following transplanting.
\end{abstract}

Container-induced root deformation can adversely affect the growth of bedding plants (Arnold et al., 1993; Latimer, 1991) and woody species (Nichols and Alm, 1983; Preisig et al., 1979) following transplanting. Cuttings of perennials rooted in small pots are subject to the same root deformation. Treating interior container surfaces with $\mathrm{Cu}\left(\mathrm{OH}_{2}\right)$ eliminated or reduced root deformation in Coreopsis lanceolata $\mathrm{L}$. and Chrysanthemum $\times$ superbum Bergmans ex J. Ingram (Arnold et al., 1993). In this study, we evaluated the effect of $\mathrm{Cu}(\mathrm{OH})_{2}$-treated containers on shoot and root growth of four perennial species during cutting propagation and on growth and flowering following transplanting to hanging baskets.

\section{Materials and Methods}

On 9 May 1992, 140-mm-long, stem-tip cuttings were removed from stock plants of Evolvulus glomeratus and E. tenuis. Leaves were removed from the basal $45 \mathrm{~mm}$ of the stem before inserting the basal ends of the cuttings into ProMix BX media (Premier Brands, Stamford, Conn.) in 57-mm-topdiameter $(150 \mathrm{ml})$ square pots. No rooting

Received for publication 6 June 1994. Accepted for publication 25 Nov. 1994. Florida Agricultural Experiment Station Journal series no. R-03886. Donation of Spin Out and financial assistance from Griffin Corp. are gratefully acknowledged. Technical assistance of Bonnie Coy is acknowledged. The cost of publishing this paper was defrayed in part by the payment of page charges. Under postal regulations, this paper therefore must be hereby marked advertisement solely to indicate this fact.

${ }^{1}$ Assistant Professor. Current address: Oregon State Univ.-North Willamette Research and Extention Center, 15210 NE Miley Rd., Aurora, OR 97002. ${ }^{2}$ Senior Biologist. compounds were used. Before being filled with medium, interior surfaces of half the pots were sprayed with a liquid latex $-\mathrm{Cu}(\mathrm{OH})_{2}$ compound $\left[100 \mathrm{~g} \mathrm{Cu}(\mathrm{OH})_{2} / \mathrm{liter} ; \approx 4.6 \%\right.$ metallic $\mathrm{Cu}$ equivalent], formulated as Spin Out (Griffin Corp., Valdosta, Ga.), while the other half was left untreated. Cuttings were rooted under intermittent mist ( 5 sec every $10 \mathrm{~min}$ ) in a fiberglass greenhouse providing 420 $\mu \mathrm{mol} \cdot \mathrm{m}^{-2} \cdot \mathrm{s}^{-1}$ maximum photosynthetic photon flux (PPF), $85 \%$ relative humidity, 31/26C (max/min), and natural daylengths (lat. $26.1^{\circ} \mathrm{N}$, long. $80.2^{\circ} \mathrm{W}$; Fort Lauderdale, Fla.).

On 22 June 1992, seven pots from each species $\times \mathrm{Cu}(\mathrm{OH})_{2}$ treatment combination were harvested to determine stem length and shoot (stems and leaves) and root dry weights (3 days at 70C). Roots were washed free of medium, and total root length was estimated using a line-intersect method (Tennant, 1975) before roots were dried.

Nonharvested rooted cuttings were transplanted two per pot into ProMix BX medium in 150-mm-top-diameter (1.2 liter) hanging baskets (Lerio Corp., Kissimmee, Fla.), providing seven pots for each species $\times \mathrm{Cu}(\mathrm{OH})_{2}$ treatment combination. Pots were top-dressed with $13 \mathrm{~g}$ of Osmocote $13 \mathrm{~N}-5.2 \mathrm{P}-10 \mathrm{~K}$ (GraceSierra, Milpitas, Calif.). Plants were grown in a screenhouse covered with black saran-type shadecloth providing $780 \mu \mathrm{mol} \cdot \mathrm{m}^{-2} \cdot \mathrm{s}^{-1}$ maximum PPF, average air means of $35 / 27 \mathrm{C}$ ( $\mathrm{max} /$ $\mathrm{min})$, and daily overhead irrigation supplemented with natural rainfall. On 22 July 1992 , postpropagation growth was evaluated using stem length, number of branches per stem, shoot width index [(narrowest + widest plant width perpendicular to its vertical axis)/2], shoot size index [(stem length + shoot width index)/2], and number of nonsenescent flowers.

Experimental procedure and evaluation used for Lantana camara 'Dallas Red' and $L$. montevidensis 'Alba' were similar to Evolvulus except that cuttings were stuck on 8 May 1992, and pots from each species $\times \mathrm{Cu}(\mathrm{OH})_{2}$ treatment combination were harvested $(n=7)$ or transplanted into hanging baskets on 22 June 1992.

All data were tested using analysis of variance (SAS Inst., 1989) in a two species $\times$ two $\mathrm{Cu}(\mathrm{OH})_{2}$ factorial treatment arrangement in a completely randomized design $(n=7)$. Genera were analyzed as separate experiments.

\section{Results and Discussion}

Elongation of adventitious roots stopped when root tips came in contact with the $\mathrm{Cu}(\mathrm{OH})_{2}$-treated container sidewall or bottom surface, preventing the development of a deformed root system. Root tips in contact with the $\mathrm{Cu}(\mathrm{OH})_{2}$-treated surface were blackened and swollen, with lateral root branching at least $15 \mathrm{~mm}$ behind the inhibited root tip. Foliar symptoms of $\mathrm{Cu}$ toxicity were absent. These observations are consistent with previous reports of mild $\mathrm{Cu}$ toxicity being localized to the area around the root tips of plants grown in $\mathrm{Cu}$-treated containers (Arnold and Struve, 1989; Flanagan and Witte, 1991). Roots growing within nontreated pots continued to grow along the pot-medium interface, forming a mat of roots conforming to the shape of the pot. Roots elongating along the pot-medium interface were susceptible to damage during transplanting.

After a 6-week rooting period, roots of $E$. glomeratus weighed $23 \%$ more than those of E. tenuis $(P>0.05)$, and roots of Lantana species had similar weights (mean of $42.8 \mathrm{mg}$ dry weight per plant). Cupric hydroxide treatment did not influence root, shoot, or total plant weights of Evolvulus or Lantana species (data not shown). Reported dry weight responses to $\mathrm{Cu}(\mathrm{OH})_{2}$ treatment have varied among species (Arnold et al., 1993; Beeson and Newton, 1992; Krieg and Witte, 1993).

Although root dry weight differed between species of Evolvulus, $\mathrm{Cu}(\mathrm{OH})_{2}$ treatment did not affect root dry weight of rooted cuttings. However, $\mathrm{Cu}(\mathrm{OH})_{2}$ treatment did reduce total root length and the length of the longest root for all four species (Table 1). When rooted in nontreated pots, the longest root of $E$. tenuis was longer than that of E. glomeratus, but when rooted in $\mathrm{Cu}(\mathrm{OH})_{2}$-treated pots, E. tenuis had shorter roots than E. glomeratus (significant interaction for length of longest root). Similar results were found between $L$. camara and $L$. montevidensis, but differences were nonsignificant.

After 1 month, stem length, number of lateral branches per stem, shoot width index, and shoot size index were similar for species within genera or between plants transplanted from $\mathrm{Cu}(\mathrm{OH})_{2}$-treated pots compared to plants transplanted from nontreated pots (data not shown). However, transplanting from $\mathrm{Cu}(\mathrm{OH})_{2}$-treated pots increased the number of flowers for all species in this study (Table 1). For example, E. glomeratus and $L$. montevidensis had $98 \%$ and $160 \%$ more flowers, respectively, when transplanted from 
Table 1. Influence of $\mathrm{Cu}(\mathrm{OH})_{2}$-treated pots used during propagation on root length of Evolvulus and Lantana, and on the number of flowers 1 month after transplanting from propagation pots into hanging baskets.

\begin{tabular}{|c|c|c|c|c|}
\hline Species & $\begin{array}{c}\mathrm{Cu}(\mathrm{OH})_{2} \\
\text { treatment } \\
\text { during } \\
\text { propagation }\end{array}$ & $\begin{array}{l}\text { Total } \\
\text { root } \\
\text { length } \\
(\mathrm{m}) \\
\end{array}$ & $\begin{array}{c}\text { Length of } \\
\text { longest } \\
\text { root } \\
(\mathrm{mm})\end{array}$ & $\begin{array}{c}\text { No. } \\
\text { flowers }\end{array}$ \\
\hline \multirow[t]{2}{*}{ E. glomeratus } & + & 0.46 & 61 & 26.3 \\
\hline & - & 0.55 & 102 & 13.3 \\
\hline \multirow[t]{2}{*}{ E. tenuis } & + & 0.31 & 54 & 13.0 \\
\hline \multirow{2}{*}{\multicolumn{5}{|c|}{ Significance $(P>\mathrm{F})$}} \\
\hline & & & & \\
\hline \multicolumn{2}{|c|}{ Species } & $* *$ & * & $* *$ \\
\hline \multirow{2}{*}{\multicolumn{2}{|c|}{$\begin{array}{l}\mathrm{Cu}(\mathrm{OH})_{2} \\
\text { Interaction }\end{array}$}} & $*$ & $* *$ & $* *$ \\
\hline & & NS & * & * \\
\hline \multirow[t]{2}{*}{ L. camara } & + & 0.31 & 55 & 19.7 \\
\hline & - & 0.33 & 119 & 12.6 \\
\hline \multirow{2}{*}{ L. montevidensis } & + & 0.51 & 66 & 23.7 \\
\hline & - & 0.60 & 109 & 9.1 \\
\hline \multicolumn{5}{|c|}{ Significance $(P>\mathrm{F})$} \\
\hline \multicolumn{2}{|l|}{ Species } & ** & NS & NS \\
\hline \multicolumn{2}{|l|}{$\mathrm{Cu}(\mathrm{OH})_{2}$} & * & $* *$ & $* *$ \\
\hline Interaction & & NS & NS & $* *$ \\
\hline
\end{tabular}

${ }^{2}$ Number of flowers per pot 1 month after transplanting.

ws, ${ }^{*, * *}$ Nonsignificant at $P>0.05$ or significant at $P \leq 0.05$ or 0.01 , respectively.

$\mathrm{Cu}(\mathrm{OH})_{2}$ pots than from nontreated pots. Improved flowering after transplanting from $\mathrm{Cu}(\mathrm{OH})_{2}$-treated pots was also reported for Impatiens wallerana Hook $\mathrm{f}$., but not for $C$. $\times$ superbum, Pelargonium $\times$ domesticum $\mathrm{L}$., or Tagetes patula L. (Arnold et al., 1993). By increasing the number of flowers on shoots of similar size, transplanting from $\mathrm{Cu}(\mathrm{OH})_{2}^{-}$ treated pots improved the overall appearance of all four species in hanging baskets. Evolvulus glomeratus had more flowers than E. tenuis, but the two Lantana species had a similar number of flowers.

Roots of rooted cuttings elongating along the pot-medium interface in nontreated pots were susceptible to damage during transplanting. While increased potential for injury did not influence vegetative growth after transplanting, plants from nontreated pots had fewer duced root length, and enhanced flowering following transplanting. The potential of $\mathrm{Cu}(\mathrm{OH})_{2}$ treatment to increase the number of flowers should be investigated on a wider range of species.

\section{Literature Cited}

Arnold, M.A., D.L. Airhart, and W.E. Davis. 1993. Cupric hydroxide-treated containers affect growth and flowering of annual and perennial bedding plants. J. Environ. Hort. 11(3):106110.

Arnold, M.A. and D.K. Struve. 1989. Cupric carbonate controls green ash root morphology and root growth. HortScience 24:262-264.

Beeson, R.C. and R. Newton. 1992. Shoot and root responses of eighteen southeastern woody landscape species grown in cupric hydroxide-treated containers. J. Environ. Hort. 10(4):214-217.

Flanagan, P.C. and W.T. Witte. 1991. Effects of chemical root pruning on root regeneration and cellular structure of viburnum root tips. Proc. Southern Nurserymen's Assn. Res. Conf. 36:4659.

Krieg, R.J. and W.T. Witte. 1993. Efficacy of a cupric hydroxide/latex paint formulation for root pruning 41 species of containerized nursery stock. Proc. Southern Nurseryman's Assn. Res. Conf. 38:129-131.

to plants transplanted from $\mathrm{Cu}(\mathrm{OH})_{2}$-treated pots.

Root length was a sensitive indicator of root growth regulation by $\mathrm{Cu}(\mathrm{OH})_{2}$ during propagation. While root weight is more easily determined, it is generally accepted that root absorption of water and minerals is more directly related to root length than to root weight. For example, when irrigation was withheld after cuttings had rooted in pots, E. tenuis and L. camara plants wilted at dawn 1 day sooner than E. glomeratus and L. montevidensis, respectively. Evolvulus glomeratus and $L$. montevidensis had 59\% and $77 \%$ more total root length compared to $E$. tenuis and $L$. camara, respectively.

Applying $\mathrm{Cu}(\mathrm{OH})_{2}$ to pots used during propagation prevented root deformation, re-
Latimer, J.G. 1991. Container size and shape influence growth and landscape performance of marigold seedlings. HortScience 26:124-126.

Nichols, T.J. and A.A. Alm. 1983. Root development of container-reared, nursery-grown, and naturally regenerated pine seedlings. Can. J. For. Res. 13(2):239-245.

Preisig, C.L., W.C. Carlson, and L.C. Promnitz. 1979. Comparative root system morphologies of seeded-in-place, bareroot, and containerized douglas-fir seedlings after outplanting. Can. J. For. Res. 9:399-405.

SAS Institute. 1989. SAS/STAT users guide. version 6. SAS Inst., Cary, N.C.

Tennant, D. 1975. A test of a modified line intersect method of estimating root length. J.Ecol. 63:9951001. 